\title{
Pohl'ady na diela zo slovenskej literárnej a výtvarnej scény
}

\author{
Gabriela Mihalková (Prešov)
}

Ján Gavura - Marta Součková (eds.): Top pät’ 2015. Slovenská literárna scéna 2015 v odbornej reflexii. Fintice: Face, 2019. 158 s. ISBN 978-80-89763-40-5.

„Ked' analyzujeme literatúru, hovorime o literatúre, ked' ju hodnotime, hovorime o sebe."

Northrop Frye

Sedem kníh projektu Top pät', vydaných medzi rokmi 2012 až 2020, ponúka literárnokritické analýzy vždy piatich kníh poézie, piatich próz a navyše predstavuje slovom a často aj obrazom (reprodukciou) zvyčajne pät výnimočných výtvarných počinov, ktoré vznikli v jednom roku na Slovensku, a doteraz boli hodnotené roky 2010 až 2016. Top pät' vzniká s istým, najprv dvojročným, naposledy takmer štvorročným odstupom, ktorý umožňuje lepšie posúdit relevantnost prozaických, básnických a výtvarných diel v kontexte slovenskej kultúry, a tak naplnit ambíciu prezentovat to najzaujímavejšie z umeleckej produkcie daného roka. Odstup medzi posudzovaným obdobím a vydaním Top pät’ umožňuje tiež v jednotlivých štúdiách prehodnocovanie doterajšej reflexie diela. Dialóg s literárnou kritikou dopĺňa často aj kritický dialóg s dielom samotným, lebo cielom minucióznych interpretácií nie je glorifikácia diela, ale precízne pomenovanie jeho esteticky funkčných či nefunkčných prvkov. Navyše, dialóg je aj určujúcou metódou pri vzniku Top pät', výber jednotlivých diel je výsledkom dialógu širšej skupiny literárnych vedcov so zostavovatelmi, Martou Součkovou a Jánom Gavurom.

Tu recenzovaná Top pät’ 2015 reflektuje texty staršej generácie spisovatelov debutujúcich v šestdesiatych, sedemdesiatych a osemdesiatych rokoch 20. storočia ako Ján Buzássy (1935), Dušan Dušek (1946) a Juraj Kuniak (1955), ale aj tých s oneskorenou habilitáciou ako Irena Brežná (1950), ktorá vstúpila do slovenskej li- teratúry po roku 1989, alebo Milan Adamčiak (1946-2017) so zbierkami vydávanými od roku 2011. Dnes už strednú generáciu slovenských spisovatelov debutujúcich v devätdesiatych rokoch 20. storočia zastupujú mená ako Luboš Bendzák (1966), Peter Macsovszky (1966), Vladimír Balla (1967), Jana Beňová (1974) a Michal Habaj (1976). Na rozdiel od predchádzajúcich Top pät'v tomto ročníku nebola zastúpená najmladšia generácia slovenských autorov, hoci aj v roku 2015 publikovali kvalitné texty.

Top pät 2015 sa začína pohladmi na poéziu. Výber z tvorby klúčového reprezentanta intermediality, experimentu, ale aj konkrétnej poézie na Slovensku, Milana Adamčiaka vyšiel v 4 zväzkoch, analýza zväzku Performatívna poézia bola súčastou Top pät' 2011, druhý zväzok, nazvaný Archív II (KOPO) - Konkrétna poézia 1964 - 1972 interpretuje v Top pät 2015 Jaroslav Šrank v kontexte doterajšej pomerne skromnej literárnovednej reflexie Adamčiakovej poézie aj v kontexte ostatnej Adamčiakovej tvorby, identifikuje jej vrcholy, eviduje, popisuje a hodnotí súčasti knihy. Šrank situuje Adamčiakovu poéziu v rámci slovenskej literatúry viacnásobným použitím slova okraj („na okraji“ či až ,za okrajom“, s. 15, 19). Rekonštruuje počiatky tvorby Adamčiaka, predstavuje jeho tematické preferencie (1. indivíduum $\mathrm{v}$ sociálnych vztahoch, 2. všedný život, 3. reflexia umenia, 4. konceptuálna tematika) a konštatuje obsahovú heterogénnoste aj v prípade interpretovaného zväzku. $\mathrm{V}$ informačne naplnenej štúdii sa z pojmov ako elektronická literatúra, konceptuálne umenie, intermediálna tvorba, fónická, optická, experimentálna, vizuálna či performatívna poézia do popredia dostáva pojem procesuálna poé- 
zia, ktorým Šrank charakterizuje Adamčiakovu tvorbu.

Druhá štúdia Top pät’ 2015 predstavuje poetiku Michala Habaja, podla Ivany Hostovej od debutu tvorenú na pozadí javov ako sprostredkovanost’ a falzifikácia autentickosti. Postmodernost z devätdesiatych rokov 20. storočia podla Hostovej dnes vystriedala transpostmoderna, digi modernizmus, kozmoderna a konkrétne Habajov postup charakterizuje transgresia v rámci postkonceptuálneho umenia. Interpretácia poučená angloamerickým teoretickým diskurzom, terminologicky presýtená kontextualizuje Habajovu poéziu v internacionalizovanom svete kultúry. Ivana Hostová nečíta komplexne, ale výberovo, lebo inak sa ani nedá.

Výber textov, ktoré majú reprezentovat kvalitu v slovenskej literárnej tvorbe za rok 2015, neznamená automaticky ich konformnú interpretáciu, nekritický obdiv, naopak, v prípade štúdie Lenky Šafránovej bol zvolený presne opačný postup. Napriek tomu, že zbierka Juraja Kuniaka Za mestom je súčastou Top pät' 2015, štúdia odkrýva skôr nedostatky, neinvenčnost̉ zbierky. $\mathrm{Na}$ rozdiel od terminologicky presýtenej štúdie Hostovej rátajúcej s poznaním kontextov, Šafránovej analýza viac ozrejmuje, jednotlivé tvrdenia explikuje, ak používa ako klúčový termín interpretácie „experienciálnost’opisu“, venuje priestor aj ozrejmeniu jeho významu.

Terminologicky tradičná je interpretácia zbierky L'uboša Bendzáka Pohreb andulky a iné udalosti dña Petra Triznu, ktorý konštatuje „využívanie epického podložia spojené s akcentovanim každodenného života lyrického subjektu“ (s. 51). Trizna tvorí mozaiku metatextov, necháva hovorił viac iných literárnych kritikov, komentuje ich rozdielne názory, hodnotenia Bendzákovej poézie, najmä antonymný prístup J. Gavuru a L. Schmarcovej. Prechádza jednotlivé oddiely zbierky, každý charakterizuje, upozorňuje na kvality, ale aj klišé v Bendzákovej poézii.

Štúdia Jána Gavuru, uzatvárajúca časț Top pät’ 2015 o poézii, sa zamerala na zbierku Jána Buzássyho Na mieste a na rozdiel od iných obsahuje aj verzologické informácie spojené s interpretáciou významov. Analýza jazyka, formy sa prelína s hladaním zmyslu jednotlivých motívov i celku, Gavura uplatňuje podnetný semiopoetický prístup. Píše o polysémantickosti Buzássyho zbierky prejavujúcej sa v okruhoch ako záhrada, spoločenstvo, privátne aj artificiálne javy, venuje sa básňam jednotlivo a interpretačne presne, zároveň však bez nároku na definitívne vysvetlenie.

Prozaickú čast Top pät 2015 otvára rozbor knihy Petra Macsovszkého Tantalópolis v komparácii s Mykat’ kostlivcom (2010), ktoré Pavol Markovič zo žánrového hladiska hodnotí ako diela relativizujúce tradičné slohovo-typologické ukotvenia. Zameriava sa na analýzu architektoniky textu, na jednej strane uvažuje o nepretržitom toku, kohéznosti, kontinuite, na druhej strane o lomenom, segmentovanom naratíve, text pokladá „za súbor plastických segmentov“ (s. 82). Klúčové slovo Markovičovej interpretácie - segmentácia - sa uplatnilo nielen v analýze kompozičnej roviny Macsovszkého prózy, ale aj jej sémantickej a syntaktickej roviny.

Štúdia Karola Csibu o románe Ireny Brežnej Nevdačná cudzinka z časti založená na reflexii metatextov, pracujúca s citátmi V. Ballu, J. Cvikovej, R. Passiu a M. Součkovej, ponúka tiež vlastnú komparáciu dvoch priestorov tematizovaných v románe, Československa ako priestoru nehybnosti, totalitných obmedzení, pravidiel, neslobody a Švajčiarska ako priestoru disciplinovanej demokracie, pričom Brežnej obraz týchto priestorov nie je čierno-biely, lebo hovorí o materskej domovine a otcovskej zemi.

Milan Kendra prostredníctvom dôsledne vyargumentovaného literárnoteoretického postupu odkrýva textotvorné procesy Dušana Dušeka v knihe Ponožky pred odletom a pomenúva ich úskalia ako neprítomnost' súhry medzi významom a výrazom, presun tažiska na tvar (gramatika, tektonika textu), tematická redundancia. Na rozdiel od Karola Csibu, ktorý sa osobitne venuje jednotlivým odborným interpretáciám diela Ireny Brežnej, Milan Kendra tu zakomponúva citáty z odbornej literatúry do vlastnej interpretácie a nemusí vždy s nimi súhlasit (napríklad na rozdiel od A. Parížekovej nepokladá Dušeka za autora postmoderny), vedie s nimi 
zmysluplný dialóg a necháva odzniet aj dialóg medzi už publikovanými literárnokritickými textami, aby tak boli identifikované podstatné vlastnosti Dušekovho naratívu: vztah k hypertextu ako k priestoru kultúrnej pamäti, semiotizácie, prítomnost̉ implikovaného autora, autoreferenčnost', tematizácia starnutia.

Štúdia Márie Klapákovej sa zaoberá výrazom a významom prózy Jany Beňovej Honeymoon a ako jej klúčové znaky identifikuje neurčitost', nejasnost', otvorenost'. Interpretáciu zásadným spôsobom určuje snaha o čítanie Beňovej cez pojem japonskej estetiky „wabi - sabi“. V dostatočne otvorenom texte dokáže zručný interpret nájsț takmer čokolvek, no samotná Klapáková priznáva aj slabiny tohto postupu, ked’že upozorní na absenciu filozofického podložia „wabi - sabi“ v Beňovej próze, a ani usúvztažnenie „wabi - sabi“ s rustikálnym nemá v nej dostatočnú oporu.

Poslednou analyzovanou knihou Top pät 2015 je Ballova Vel'ká láska, ktorú autorka štúdie, Marta Součková, žánrovo označuje ako novelu, odvolávajúc sa na genologicky nie celkom presné vyjadrenie Zoltána Rédeya, že Ballov text „nepodriaduje sa sujetovej logike a osnove typickej pre román" (s. 126). Neprítomnosṫ štruktúry balzakovského typu románu neznamená, že ide automaticky o novelu, napokon, samotná štúdia Součkovej odkrýva také znaky Ballovho naratívu ako fragmentárnost', epizodickost', digresívnost', ktoré sú v rozpore s novelistickým tvarom vyžadujúcim kompozičnú zovretost', redukciu digresií, intenzifikáciu času fabuly, intenzívnost? namiesto extenzie. Cielom štúdie však nebola genologická analýza, ale interpretácia Ballových tém tak, ako ich reprezentujú jednotlivé postavy vo vzájomných vztahoch a rolách (ne/normalita, ne/závislost', reflexia literatúry, kultúry).

Top pät 2015 sa v časti zameranej na slovenskú výtvarnú scénu vymyká z doteraz používanej koncepcie, kým v predchádzajúcich Top pät’ tu boli štúdie približujúce projekty piatich výtvarníkov, tentoraz teoretička výtvarného umenia, Jana Migašová, ponúka pohlad na tvorbu dvoch vítazov Ceny Oskára Čepana 2015, Jána Zelinku (1978) a Radka Brousila (1980). V prípade Zelinku predstavuje genézu jeho sochárskeho vyjadrenia a v prípade Brousilu postmoderné upriamenie sa na komunikáciu média o médiu, o jeho možnostiach.

Súhrne, Top pät’ 2015 obsahuje štúdie hladajúce kultúrne (minimálne európske) kontexty (I. Hostová, J. Migašová), mimoeurópske kontexty (M. Klapáková), štúdie - interpretácie (M. Součková, L. Šafránová), ale aj mozaiky interpretácií iných (P. Trizna), štúdie zamerané na komunikáciu medzi tvarom a významom (J. Gavura), terminologicky presýtené (I. Hostová, M. Kendra), ale aj štúdie terminologicky tradičné (P. Trizna). Väčšina štúdií usúvztažňuje analyzovaný text s predchádzajúcou tvorbou autora, hladá jeho kvality, ale konštatuje aj prítomnost̉ miest nekvalitných (ošúchanost̉ výrazu a obrazu v poézii Bendzáka, Kuniaka). Top pät 2015 ponúka zaujímavé čítanie nielen z hladiska toho, o čom sa tu píše, ale vd’aka rôznosti zvolených metodologických prístupov aj z hladiska toho, ako sa o tom píše.

doc. PhDr. Gabriela Mihalková, PhD.

Katedra slovenskej literatúry a literárnej vedy

Inštitút slovakistiky a mediálnych štúdií

Filozofická fakulta, Prešovská univerzita v Prešove

17. novembra 1, 08001 Prešov, SK

gabriela.mihalkova@unipo.sk

This work can be used in accordance with the Creative Commons BY-SA 4.0 International license terms and conditions (https://creativecommons.org/licenses/by-sa/4.0/legalcode). This does not apply to works or elements (such as image or photographs) that are used in the work under a contractual license or exception or limitation to relevant rights. 